JOURNAL OF SECURITY AND SUSTAINABILITY ISSUES

ISSN 2029-7017 print/ISSN 2029-7025 online

2021 Volume 11

https://doi.org/10.47459/jssi.2021.11.43

\title{
THE USE OF UNMANNED AERIAL VEHICLES BY THE POLISH POLICE
}

\author{
Marlena Lorek ${ }^{1}$, Marek Magniszewski ${ }^{2}$ \\ 1,2Rzeszów University of Technology, Aleja Powstańców Warszawy 12, 35-959 Rzeszów, Poland \\ E-mails: ${ }^{1} m l o r e k @ p r z . e d u . p l ;{ }^{2} m m a g n i s z e w s k i @ p r z . e d u . p l$
}

Received 18 August 2021; accepted 07 October 2021; published 30 October 2021

\begin{abstract}
The aim of this article is to show the impact of unmanned aerial vehicles (UAVs) and how their support helps the police in activities for the security of our country. Let us ask ourselves whether drones, as these mobile devices, are able to support various types of campaigns carried out by many uniformed services in Poland faster and easier. The police, using the latest techniques for reconnaissance and operational activities, can successfully indicate that UAVs are very necessary and facilitate work, especially in difficult conditions that are difficult for humans. That is why the policemen are trained on an ongoing basis in the field of UAV service so that they can effectively use the equipment for work, which was also indicated in their tasks. Increasingly, monitoring of the so-called in advance, it allows you to quickly reach the threat or people who threaten and want to commit acts that do not comply with applicable law.
\end{abstract}

Keywords: unmanned aerial vehicles; law; police; police tasks; use of UAVs; security

Reference to this paper should be made as follows: Lorek, M., Marek Magniszewski, M. 2021. The use of unmanned aerial vehicles by the polish police. Journal of Security and Sustainability Issues, 11, 481-488. https://doi.org/10.47459/jssi.2021.11.43

JEL Classifications: K14

Additional disciplines: law

\section{Introduction}

In the age of technology development, more and more machines and devices for better functioning can be used. Mobile inventions are an inseparable zone of our lives, and progress causes the recipients to adapt to technical novelties such as telephones, tablets or others, by means of which we can provide information, knowledge as well as perform basic professional duties. Technology also influences the fact that more and more often we reach for even newer solutions, which may also facilitate our daily functioning. Currently, you can see how fashionable it has become to have drones, i.e. unmanned aerial vehicles that are often used for recreational and hobby purposes. The use of such a device allows you to better capture holidays, special events or even monitoring the developing nature. However, be aware that there is privacy and you cannot use the UAV to monitor people who are uninformed, as it is not legal to photograph or record someone's private life.

In addition, the development of civil aviation has also forced states and international organizations to create appropriate legal solutions that will ensure safety in the airspace. They had to indicate who can operate them, for what mass are required permits and appropriate permissions for the UAV's movement in the territory of our country.

The police are a unit that watches over the level of safety and public order, which is why they use drones to deal with various types of threats in order to be able to reach such places as soon as possible and prevent their creation or spread. Nevertheless, the possession of such devices requires from the officers even greater knowledge and skills in reconnaissance activities. 


\section{Characteristics of unmanned aerial vehicles}

Currently, many tasks related to ensuring safety and public order using unmanned aerial vehicles (UAV) are carried out in the world. In terms of security, the Polish police use these new measures to help in the implementation of tasks assigned to them to secure the health of life and property of citizens. The police try to constantly improve the skills of officers in the use of these devices so that they can be used in various areas of the service. The knowledge gained during the trainings can help both during search and reconnaissance actions in order to verify the threat we are dealing with. These funds can be used primarily in field operations, because the police can efficiently and quickly reach places that are hard to reach, such as: water, marshes, floodplains or slopes, cliffs or difficult forest areas (Kuptel 2014).

Drones in the Polish market have been intensively used for several years, because previously uniformed services were not equipped with such devices to support their activities. Their first activities were directed only to military and reconnaissance activities, and only now are they used to search for and identify threats that officers of many uniformed services in Poland face in their daily professional duties. In addition, they were used as a tool in trade or other commercial applications. Currently, they are also assisted in collecting data and processing them for topographic or reconnaissance purposes of the area (Karpowicz, Kozłowski 2003)

Colloquially called unmanned aerial vehicle (UAV), also known as a drone, it is nothing else than remote piloting using an autonomous device that performs flight operations. In addition, the drone is not crewed and is fully controlled by the operator. These ships are used for civilian use and are used for transport through ICT activities and are used, inter alia, for filming, photography, agriculture, rescue and many other economic areas. More and more drones are used for marketing purposes, for example in the media or marketing of beautiful areas of our geographical space. They are much cheaper to operate, which is why they already replace planes and helicopters that previously carried out the above activities. Unmanned aerial vehicles are used in the geodetic and GIS industry. They are used for geodetic and cartographic measurements. They are often used to obtain geospatial data in hard-to-reach areas. Equipped with sensors such as: (laser scanners, cameras and digital cameras), the drone can be used in various industries. The main advantage of the drone is that it is able to collect high-quality data in a short time.

Flights under VLOS (Visual Line of Sight - so-called operations within the operator's sight) in Poland were included in the Regulation of the Minister of Transport, Construction and Maritime Economy of March 26, 2013 y. (Regulation of the Minister of Transport 213). (see Table 1).

Table 1. Classification of UAVs

\section{NATO UAV classification}

\begin{tabular}{c|l} 
Class I & $\begin{array}{l}\text { weight: }<150 \mathrm{~kg} \text {; } \\
\text { application: supporting operations at the tactical level, i.e. at the team, platoon or company level; flight time: up to } 6 \mathrm{~h},\end{array}$ \\
\hline Class II & $\begin{array}{l}\text { weight: } 150-600 \mathrm{~kg} ; \\
\text { application: supporting operations at the tactical level, i.e. at the battalion or brigade level; flight time: up to } 24 \mathrm{~h},\end{array}$ \\
\hline Class III & $\begin{array}{l}\text { weight: }>600 \mathrm{~kg} ; \\
\text { application: support for operations at the operational and strategic level; flight time: up to } 40 \mathrm{~h} \text { important information: high } \\
\text { altitude operations }(>3000 \mathrm{~m}) .\end{array}$
\end{tabular}

Source: according to NATO from 2009, based on: P. Sawicki, UAV unmanned aerial vehicles in photogrammetry and remote sensing - current state and development directions (In :) Archive of Photogrammetry, Cartography and Remote Sensing, 2012, No. 23, p. 366 (Sawicki 2012).

The classification of unmanned aerial vehicles is not so obvious as there is no uniform classification and therefore it is difficult to identify its individual elements. In the international aviation community, it was not possible to select such a uniform typology for UAVs. However, they have been divided into several criteria that may indicate what is taken into account during the extraction. In Polish law, such a classification of UAVs can be distinguished depending on the design or their purpose (Karpowicz, Kozłowski 2003). 
In the case of weight, UAVs are distinguished:

- from 0 to $5 \mathrm{~kg}$,

- from 5 to $25 \mathrm{~kg}$,

- from 25 to $150 \mathrm{~kg}$ (see Table 2).

Table 2. UAV classification by weight

\begin{tabular}{|c|c|c|}
\hline \multicolumn{2}{|c|}{ UAV classification by weight } \\
\hline Designation & Mass & UAV example \\
\hline$[$ Super Heavy $]$ & $>2000 \mathrm{~kg}$ & RQ-4 Global Hawk \\
\hline$[$ Heavy $]$ & $200-2000 \mathrm{~kg}-160$ \\
\hline$[$ Medium $]$ & $50-200 \mathrm{~kg}$ & Raven \\
\hline$[$ Light $]$ & $5-50 \mathrm{~kg}$ & RPO Midget \\
\hline Very light $[$ Micro] & $<5 \mathrm{~kg}$ & Dragon Eye \\
\hline
\end{tabular}

Source: based on: M. Nowakowski, G. Polak, Analysis of legal and technical conditions for the use of unmanned aerial vehicles in the airspace, Technika no. 12/2015, p. 2771-2775.

According to the construction, the following are listed:

- unmanned aerial vehicle (A),

- unmanned airship (AS),

- unmanned helicopter $(\mathrm{H})$,

- unmanned multi-rotor (MR),

- other unmanned aerial vehicle (O).

Due to the purpose or type of operation, there are two basic types of drones:

- models flying to a take-off mass not exceeding $150 \mathrm{~kg}$, they are only used in operations for the visual range and are used for recreational or sports purposes,

- unmanned aerial vehicles with a take-off mass not exceeding $150 \mathrm{~kg}$ used exclusively in operations within the visual range for purposes other than recreation or sport. Visual line of sight operation (VLOS) is an operation in which the operator and the observer of the flying model maintain direct eye contact with the machine.

Another distinction of unmanned aerial vehicles are those that are already beyond the visual line of sight (BVLOS) in this operation, both the operator and the observer do not maintain direct eye contact with the machine. It is worth adding that BLOVS flights can be performed in zones designated for this and separated by public aviation air spaces. In order to be able to perform such flights, appropriate forms must be submitted for this purpose at least 120 working days before the plans to organize such a flight. The Polish Air Navigation Services Agency may issue such decisions that will allow such air operations. Here the following are taken into account:

- flight time,

- airspace class,

- weight,

- destiny,

- ceiling,

- type of drive,

- kind of operation,

- type of construction,

- reception,

- application (see Table 3). 
Table 3. Industry BSP classification

\begin{tabular}{|c|c|c|c|c|c|}
\hline \multicolumn{2}{|r|}{ Categories } & \multirow{2}{*}{$\begin{array}{c}\text { Range (km) } \\
<1\end{array}$} & \multirow{2}{*}{$\begin{array}{c}\text { Flight altitude (m) } \\
100\end{array}$} & \multirow{2}{*}{$\begin{array}{c}\text { Flight time (h) } \\
<1\end{array}$} & \multirow{2}{*}{$\begin{array}{c}\text { MTOM (kg) } \\
<0,025\end{array}$} \\
\hline \multirow{10}{*}{ 胥 } & Nano & & & & \\
\hline & Mikro & $<10$ & 1500 & 1 & $<5$ \\
\hline & Mini & $<10$ & 150 & $<2$ & $<30$ \\
\hline & Close Range (CR) & $30-70$ & 3000 & $2-4$ & 150 \\
\hline & Short Range (SR) & $>500$ & 3000 & $3-6$ & 200 \\
\hline & Medium Range (MR) & $70-200$ & 5000 & $6-10$ & 1250 \\
\hline & Medium Range Endurance (MRE) & $>500$ & 8000 & $10-18$ & 1250 \\
\hline & Low Altitude Deep Penetration (LADP) & $>250$ & $50-9000$ & $0,5-1$ & 350 \\
\hline & Low Altitude Long Endurance (LALE) & $>500$ & 3000 & $>24$ & $<30$ \\
\hline & Medium Altitude Long Endurance (MALE) & $>500$ & 14000 & $24-48$ & 1500 \\
\hline 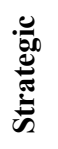 & High Altitude Long Endurance (HALE) & $>2000$ & 20000 & $24-48$ & 12000 \\
\hline \multirow{6}{*}{ 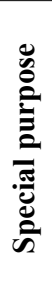 } & Unmanned Combat Aerial Vehicle (UCAV) & 1500 & 10000 & 2 & 10000 \\
\hline & Offensive (OFF) & 300 & 4000 & $3-4$ & 250 \\
\hline & Decoy $(\mathrm{DEC})$ & $0-500$ & 5000 & $<4$ & 250 \\
\hline & Stratosferyczny (STRATO) & $>2000$ & $>20000-30000$ & $0>18$ & $\mathrm{Na}$ \\
\hline & Pozastratosferyczny (EXO) & $\mathrm{Na}$ & $>30000$ & $\mathrm{Na}$ & $\mathrm{Na}$ \\
\hline & Kosmiczny (SPACE) & $\mathrm{Na}$ & $\mathrm{Na}$ & $\mathrm{Na}$ & $\mathrm{Na}$ \\
\hline
\end{tabular}

Source: based on The global perspective. 15th edition, UVS International, 2018, p. 124.

The next specification of parameters concerns, among others:

- calibration time,

- battery and apparatus charging time,

- battery replacement time,

- hovering accuracy,

- maximum flight speed,

- support for Micro SD memory cards,

- warranty period,

- flight programming and autonomy,

- sensors for detecting obstacles,

- folding chassis,

- operating temperature,

- range of transmission or image from the camera.

The police is a public administration body that has been shaped in various ways over the years. It is an armed and uniformed formation with rights and obligations aimed at protection, and upholds the law, as well as security and public order (Kalina-Prysznic 1990). Mainly, the police were to assist the state in enforcing obligations from citizens who were to strictly obey them and comply with the applicable law. The term "police" is derived from the Greek word politeja, which means city management. Successively, the word was adopted by the Latin language as politia (Izdebski 1996). The police support many public and local government organizations in their activities. Together, they create and support each other in activities to protect citizens. However, if this safety is at an appropriate level for supporting activities, you can now use new techniques of operation, such as drones, which can easily and quickly reach the place of danger, even when the terrain is difficult and difficult for an officer to access (Tarno 2005). 
The police, like any organization, is established to ensure safety and public order, has its own organizational structure, thanks to which the duties are assigned according to the appropriate professional competences of officers. This structure introduces a specific order, which makes it possible to designate units and cells within this formation for activities related to, for example, the operation of unmanned aerial vehicles (Boć 2000).

The Police is a formation included in the public administration, therefore it is obliged to act in the public interest. This activity must be within the limits laid down by law (Leoński 2004).

The main scope of the Police's tasks has been defined by the Act on the Police. The tasks of the Police also result from other laws and international agreements (Lorek 2017).

The basic tasks of the police include:

- protection of the health and life of citizens against unlawful attacks,

- ensuring safety and order in public places, as well as in public transport, public transport, road traffic and waters in our country,

- organization and initiation of activities to prevent offenses and criminogenic crimes,

- cooperation with local and state authorities as well as other social organizations,

- detection and prosecution of perpetrators of crimes,

- supervising the work of the city guard and other armed security formations in the field of security, which have been included in separate regulations,

- controlling administrative and order regulations in the field of public activity,

- Police cooperation at the international level on the basis of contracts and agreements contained in separate regulations,

- collection, processing and transmission of information of a criminal nature;

- creating and maintaining a database containing information on the results of deoxyribonucleic acid (DNA) analysis (M. Jurgilewicz 2017, Art. 1. Act. 2 of the Act of April 6, 1990).

\section{The use of unmanned aerial vehicles by the police in Poland}

Activities related to the use of unmanned aerial vehicles in Poland are quite wide and they include, first of all:

- supervision,

- counter-terrorist activities,

- identification of people,

- inspections of dangerous places or objects,

- monitoring of mass events,

- road monitoring,

- tracking people,

- observation of the place of the event,

- patrolling,

- searching,

- chases,

- rescue,

- training and training,

- transporting and discharging chemical incapacitating agents or other agents that are required in a given situation or operation. 
Unmanned aerial vehicles have many functions and parameters that are used in various types of missions. Most often, they are used for night activities because it is easiest to reach places that are not lit and hard to reach. Search and rescue activities are characterized by the fact that you have to get to the threat very quickly and the drone is a device supporting such missions. The most important thing is that during such an operation, the drone should have the longest range and also have a thermal imaging camera installed, which will allow you to search the selected area.

The next steps are counter-terrorism, and here, however, the flight time is not so important as the size and noise level of the device, which should be hardly noticeable to the enemy and could support the actions of the officers.

However, in the case of tracking or patrolling, the most important thing is the zoom of the camera and the function (point of interest), which consists in the fact that the drone flies around a point or object designated in space and constantly makes contact, which it maintains continuously and the target is in camera frame range.

All the above activities show how much commitment the operator puts because he has to designate the facility, adjust the appropriate height, speed and length of the route, because then we can talk about good organization of work and appropriate division of roles of the team that supports BSP activities and then we can talk about the success of the mission. The pilot usually focuses on operating the UAV and the camera operator on capturing what can help in further police actions. Nevertheless, in the Polish police, this model of cooperation is most often used, because everyone can focus fully on their tasks. Such cooperation and division of roles is very important, because UAV handling is not so easy and requires full concentration on the part of the pilot, therefore the separation of these responsibilities is very important due to the quality and efficiency of operations.

\section{Legal basis for performing flights with unmanned aerial vehicles}

In Poland, there are conventions, laws and legal provisions, both at the national, EU and international level. The most important thing is also the purposes for which the UAV will be used, because then the operators will be bound by the relevant legal regulations. It is also worth knowing for what purposes the operator will be using UAVs, whether they will be sports and recreational or other than sports and recreational.

The most important of them include:

- Convention on International Civil Aviation of December 7, 1944, of December 7, 1944, signed in Chicago (Journal of Laws 1959, No. 35, item 212, as amended),

- Aviation Law of July 3, 2002 (Journal of Laws of 2018, item 1183),

- Regulation of the Minister of Transport, Construction and Maritime Economy on the classification of aircraft of August 7, 2013 (Journal of Laws of 2018, item 1568),

- Ordinance of the Minister of Transport, Construction and Maritime Economy on the exclusion of the application of certain provisions of the Aviation Law Act to certain types of aircraft and specifying the conditions and requirements for the use of these ships of March 26, 2013 (Journal of Laws of 2016, item 1993, as amended),

- Regulation of the Minister of Transport, Construction and Maritime Economy on technical and operational regulations for special category aircraft not covered by the supervision of the European Aviation Safety Agency of April 26, 2013 (Journal of Laws of 2018, item 1122),

- Regulation of the Minister of Transport, Construction and Maritime Economy on qualification certificates of June 3, 2013 (Journal of Laws of 2013, item 664, as amended),

- Regulation of the Minister of Infrastructure of June 11, 2010 on flight bans or restrictions for a period longer than 3 months (Journal of Laws 2010 No. 106, item 678, as amended),

- Commission Implementing Regulation (EU) No 923/2012 of 26 September 2012 establishing common rules of aviation and operational rules for air navigation services and procedures,

- Regulation (EU) 2018/1139 of the European Parliament and of the Council of 4 July 2018 on common rules in the field of civil aviation and establishing a European Union Aviation Safety Agency. 


\section{Conclusions}

Modern technologies have a positive impact on our development, often innovations introduce new space, for example, to counteract threats that we may have to deal with or even to react quickly, which is a priority in combating the threats that arise. Security is the most important element for any society, therefore many public administration bodies should constantly strive to develop in order to protect them. Currently, many services in the territory of the Polish state already use unmanned aerial vehicles. The police have also been included in this support, thanks to which officers can react faster and easier to threats. They often perform activities to ensure safety and public order. The most important thing is the health, life and property of the citizen, therefore the new possibility of faster response to them is appropriate for securing the borders of our country. The most important thing is that all UAV users use them as intended and in accordance with applicable legal regulations, so that there are no threats from the pilot or UAV operator. The police mainly use UAVs to search for missing persons as well as to identify and prevent them in order to be able to reach their destination as soon as possible. Adequate training of officers is essential, as it will be important in terms of the speed with which the mission has been carried out by their superiors in accordance with the tasks set out in the Police Act. Police are often assisted with unmanned aerial vehicles, however, it is difficult to determine how many such missions are annually, because statistics on such operations are not available due to safety in this area.

\section{References:}

Art. 1. Act. 2 of the Act of April 6, 1990 on the Police Art. 1. Ust. 2 ustawy z dnia 6 kwietnia 1990 y. o Policji), (Uniform text, Journal of Laws of 2007, No. 140, item 981, as amended).

Boć, J, (ed.). 2000. Administrative law (Prawo administracyjne), ed. Kolonia Limited, Wrocław.

Izdebski, H. 1996. History of administration (Historia administracji), Warsaw.

Jurgilewicz, M. 2017. The role of entities authorized to use or use means of direct coercion and firearms in the protection of public safety and order (Rola podmiotów uprawnionych do użycia lub wykorzystania środków przymusu bezpośredniego i broni palnej w ochronie bezpieczeństwa i porządku publicznego), Siedlce 2017.

Kalina-Prysznic, U. 1990. Encyclopedia of Law (Encyklopedia Prawa) ed Wyd. C.H.BECK., Warsaw.

Karpowicz, J., Kozłowski, K. 2003. Unmanned aerial vehicles and miniature flying apparatuses (Bezzałogowe statki powietrzne i miniaturowe aparaty latające), Warszawa.

Kuptel, A. 2014. The use of unmanned aerial systems in the military aspect (Zastosowanie bezzałogowych systemów powietrznych w aspekcie militarnym), Warsaw.

Leoński, Z. 2004. Outline of administrative law (Zarys prawa administracyjnego), Warsaw 2004.

Lorek, M. 2017. Motivating in the Polish Police (Motywowanie w polskiej policji), Publishing House of the Rzeszów University of Technology, Rzeszów.

Nowakowski, M., Polak, G. 2015. Analysis of legal and technical conditions for the use of unmanned aerial vehicles in the airspace, Technika, 12, p. 2771-2775.

Regulation of the Minister of Transport, Construction and Maritime Economy of March 26, 2013 (Rozporządzenie Ministra Transportu, Budownictwa i Gospodarki Morskiej z dnia 26 marca 2013 y.), on the exclusion of the application of certain provisions of the Aviation Law Act to certain types of aircraft and determining the conditions and requirements for the use of these ships, ((Journal of Laws, item 440 as amended).

Sawicki, P. 2012. UAV unmanned aerial vehicles in photogrammetry and remote sensing - current state and development directions (In:) Archives of Photogrammetry, Cartography and Remote Sensing (Bezzałogowe aparaty latające UAV w fotogrametrii i teledetekcji stan obecny i kierunki rozwoju (In:) Archiwum Fotogrametrii, Kartografii i Teledetekcji)..

Tarno, J.P. 2005. Police, as an administrative body with specific competences (Policja, jako organ administracji o kompetencjach szczególnych), (In :) Aleksander Babiński, Bogdalski P (ed.), Police in public administration structures, Szczytno.

The global perspective. 2018. 15th edition, UVS International, p. 124. 
JOURNAL OF SECURITY AND SUSTAINABILITY ISSUES

ISSN 2029-7017 print/ISSN 2029-7025 online

Dr Marlena LOREK, Rzeszów University of Technology.

ORCID: 0000-0002-6814-8162

Dr Marek MAGNISZEWSKI, Rzeszów University of Technology. ORCID: 0000-0002-9088-8159 